\title{
An adsorbed surface-antigen influenza vaccine and its serological activity in volunteers
}

\author{
M. I. BRADY \\ B.Sc., Ph.D.
}

\author{
I. G. S. FURMINGER \\ B.Sc., Ph.D.
}

\begin{abstract}
Summary
A highly purified vaccine prepared from surface antigens of influenza virus adsorbed on to aluminium hydroxide has elicited good antibody results to both haemagglutinin and neuraminidase components, and has been shown to induce resistance to homotypic challenge at a satisfactorily high level.
\end{abstract}

\section{Introduction}

The purification of influenza virus vaccine has been facilitated by two major technological advances, namely the development of zonal rotors capable of processing large volumes of fluid, and the application of surfactants, lipid solvents or proteases to disrupt the influenza virion. However, application of either of these two principles can still leave one with a vaccine which contains large amounts of matrix and nuclear proteins, which do not appear to contribute to the protective efficacy of the vaccine and are probably responsible for at least some of the local and systemic reactions occurring in vaccinated subjects.

In general, however, disruption of the virus particle is accompanied by a loss of antigenicity. The more efficient the breakdown and the more stringent the purification of selected protein fractions, the greater tends to be the overall loss of antigenicity. The surface proteins, the haemagglutinin and neuraminidase, are of relatively low molecular weight and apart from actual process losses of antigenic mass, the separated antigens appear to have less potential than does the same amount of material in the intact particle. This problem can be readily overcome by the incorporation of a mineral carrier such as aluminium hydroxide.

A vaccine consisting of haemagglutinin and neuraminidase antigens adsorbed on to aluminium hydroxide gel ('Alhydrogel') was prepared and the dose response to $0.5 \mathrm{ml}$ doses containing different amounts of antigen was studied in volunteers.

Materials and methods

Virus strains

A / England / 42/72 and A/Port Chalmers / 1/73 strains of influenza virus were obtained from the Medical Research Council Influenza Referen⿸厃㔾 Laboratories, Mill Hill, London.

\section{Virus cultivation}

Influenza virus $\left(10^{4 \cdot 0} \mathrm{EID}_{50}\right)$ was inoculated the allantoic route into 11-day-old embryonated he्g eggs $(0.2 \mathrm{ml} / \mathrm{egg})$. The eggs were incubated at $35^{\circ} \mathrm{C}$ for $48 \mathrm{hr}$. They were chilled at $4^{\circ} \mathrm{C}$ and the allantoic fluid was harvested. Beta-propiolactone was adder to the final concentration of $0 \cdot 1 \%$ to inactivate the virus.

\section{Purification of whole virus}

Allantoic fluid (140 1) containing virus was cta fied at 15,000 $\mathrm{g}$ in an Alfa-Laval centrifuge to remo gross contaminants, e.g. erythrocytes. A gradieat was established in a KII zonal rotor by addian sucrose $(60 \% \mathrm{w} / \mathrm{w} 1.41)$ to the stationary rotor and

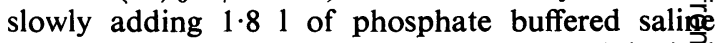
(PBS) $(0.01 \mathrm{~mol} / \mathrm{l}$ phosphate $\mathrm{pH} 7.6$ in physiologicăl saline).

The gradient was formed by centrifugation ait 3000 r.p.m. for $15 \mathrm{~min}$. The rotor was accelerate and a fast flow of PBS (20-30 1/hr) was startedi When the rotor reached a speed of 35,000 r.p. $\mathbf{m}$. $(90,000 \mathrm{~g})$ the PBS was replaced with clarified allantoic fluid at a flow rate of $30 \mathrm{l} / \mathrm{hr}$. Under these colditions virus particles entered the sucrose gradiegt and formed a band at their isopycnic density. When all the virus had been centrifuged across the gradien, the rotor was operated at $90,000 \mathrm{~g}$ for a further hour at room temperature.

At the end of centrifugation, when the rotor slowed to a halt, the gradient reorientated. Fractions wes collected and those containing a high concentration of virus were pooled and diluted to $5 \% \mathrm{w} / \mathrm{w}$ sucrose with PBS to a final volume of 101 .

\section{Disruption of virus}

A gradient was established in the KII rotor adding PBS (1.8 l) containing Triton N101 (1\%v/ to sucrose $(60 \% \mathrm{w} / \mathrm{w}$ in PBS) $(1.41)$ also containi 
Triton N101 $(1 \% \mathrm{v} / \mathrm{v})$. The gradient formed as the rotor accelerated to $90,000 \mathrm{~g}$ and the Triton micelles formed a band within minutes.

Purified virus diluted to 101 as described above was allowed to flow across this gradient and disruption occurred as the virus particles sedimented through the band of Triton. The rotor was operated for a further hour at room temperature and 90,000 $\mathrm{g}$ to separate the split products, the surface antigens sedimenting in the Triton layer, while the core and matrix proteins settled in the denser portion of the gradient.

\section{Removal of Triton}

The fractions from the gradient which contained surface proteins were pooled and phosphate buffer $(2 \mathrm{~mol} / \mathrm{l} \mathrm{pH} 7 \cdot 0)$ was added to give a final concentration of $0.5 \mathrm{~mol} / \mathrm{l}$. Under these conditions, the cloudpoint of the surfactant was exceeded at room temperature. The solution was allowed to stand at room temperature overnight and the Triton separated as a narrow upper layer, which also contained phospholipids. The lower phase containing the surface proteins of the virus was removed.

Adsorption of surface antigens to aluminium hydroxide Alhydrogel (Superphos Ltd) $\left(2 \% \mathrm{w} / \mathrm{v} \mathrm{Al}(\mathrm{OH})_{3}\right.$ in water) was added to the concentrated surface antigens after removal of Triton. The suspension was allowed to stand overnight at $4^{\circ} \mathrm{C}$ and then diluted to the required strength. Vaccines were prepared containing
400 i.u. $/ 0.5 \mathrm{ml}, 200$ i.u. $/ 0.5 \mathrm{ml}, 100$ i.u. $/ 0.5 \mathrm{ml}, 50$ i.u. $/ 0.5 \mathrm{ml}$ and 25 i.u. $/ 0.5 \mathrm{ml}$. The final vaccine contained $\mathrm{Al}(\mathrm{OH})_{3}(5 \mathrm{mg} / \mathrm{ml})$ in $0.1 \mathrm{~mol} / \mathrm{l}$ phosphate buffer.

\section{Standardization of vaccine}

The haemagglutinin content of the vaccine was standardized by radial diffusion (Schild, HenryAymard and Pereira, 1972) using antiserum prepared in rabbits to bromelain-derived haemagglutinin (Brand and Skehel, 1972). Neuraminidase was estimated by direct assay of enzyme activity in an autoanalyser (Bevan, Furminger and Smith, 1975).

\section{Electron microscopy}

Dilute samples were concentrated by sedimentation and resuspended in PBS. Samples were added to carbon-coated formvar grids and salts were removed by addition and removal of distilled water to the grid. Phosphotungstic acid $(2.5 \% \mathrm{w} / \mathrm{v}) \mathrm{pH} 6.8$ was used as a negative stain.

\section{Results}

Figure 1 shows the distribution of viral components after virus particles have been centrifuged through a sucrose gradient containing Triton N101. The protein peak at the dense end of the gradient represents the stripped particles or cores and some residual unsplit virus as indicated by the small neuraminidase peak. The protein at the top of the gradient consists of haemagglutinin and neuraminidase close to the surfactant band.

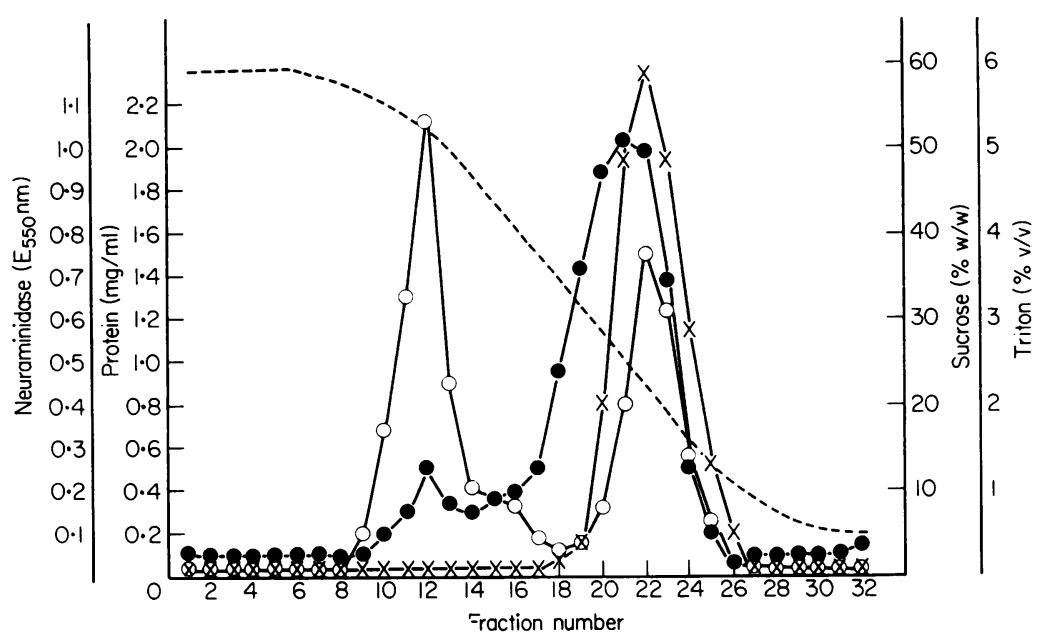

FIG. 1. Distribution of A/England/42/72 influenza proteins after centrifugation

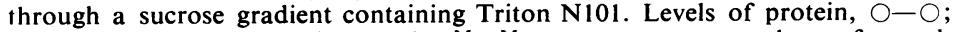
neuraminidase, - Triton $\mathrm{N} 101, \mathrm{X}-\mathrm{X}$; sucrose, .... are shown for each fraction. 


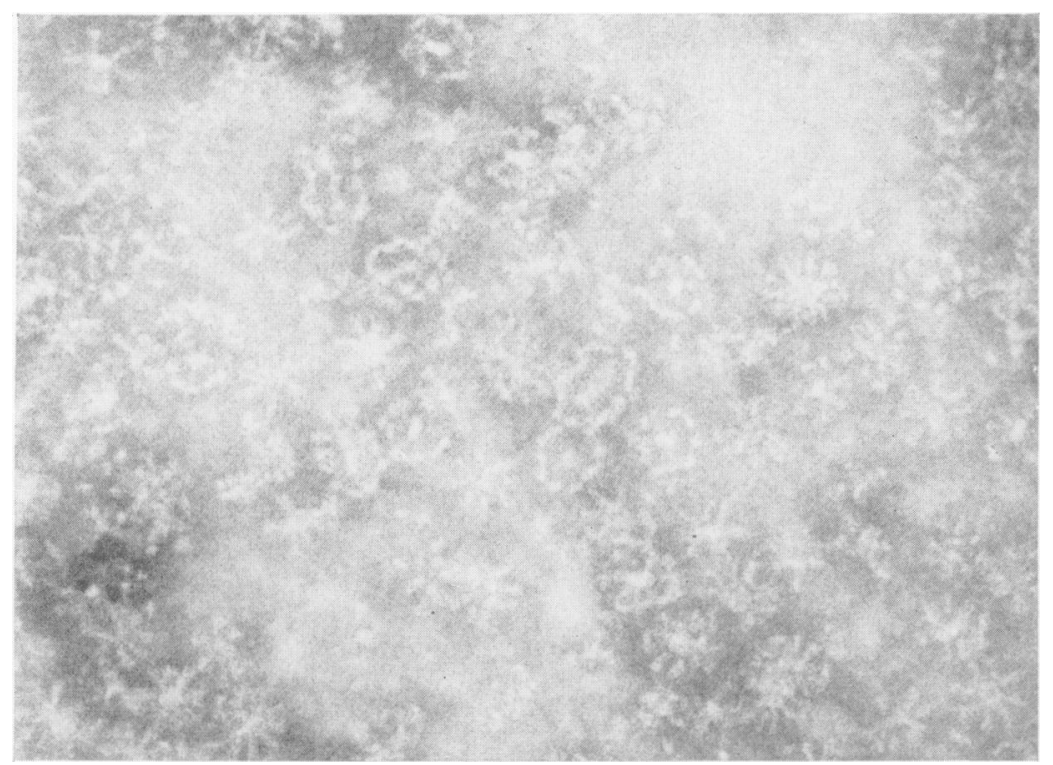

Fig. 2. Surface antigens of A/England/42/72 showing the cartwheel formations of neuraminidase and the stellate aggregates of haemagglutinin.

Figure 2 shows the effect of removing surfactant from a pool of the fractions containing haemagglutinin and neuraminidase. The two surface proteins form separate aggregates and the stellate groups of haemagglutinin particles contrast strongly with the cartwheel formations of neuraminidase. No particles of core protein were observed and specific testing with core protein antibody by radial diffusion gave a negative reaction (Oxford, 1974).

\section{Serological studies}

For studies in volunteers, serial two-fold dilutions of material prepared from the A/Port Chalmers/1/73 strain were made in aluminium hydroxide gel so that the concentration of gel was constant at $2.5 \mathrm{mg}$ per dose $(=0.86 \mathrm{mg}$ aluminium $)$ at each dose level. Subjects with no recent history of influenza-like illness and who had not received influenza vaccine within the previous 12 months were bled and their serum HI (haemagglutination inhibition) and NI titres determined. They were then distributed into groups so that the numbers with low and high HI antibody levels were evenly matched. The diluted vaccines were coded and each group was given a different dilution on a random basis. Two to three weeks later a further blood sample was taken and antibody levels again determined.

The results are shown in the following tables, the titres being shown as reciprocal values in each case. If the subjects with low HI antibody levels are considered (Table 1) there appears to be no dose response curve, even 25 i.u. producing a good level. If
TABLE 1. Haemagglutination inhibition responses of volun $\overrightarrow{0}$ teers with low antibody levels $(<1: 30)$ to A/Port Chalmôr surface antigen vaccine

\begin{tabular}{|c|c|c|c|}
\hline \multirow[b]{2}{*}{$\begin{array}{l}\text { Dose } \\
\text { (i.u.) }\end{array}$} & \multirow[b]{2}{*}{$\begin{array}{l}\text { Seroconversion } \\
\text { rate }\end{array}$} & \multicolumn{2}{|c|}{ g.m.t.* } \\
\hline & & $\begin{array}{c}\text { Pre- } \\
\text { vaccination }\end{array}$ & $\begin{array}{c}\text { Post- } \\
\text { vaccinatic }\end{array}$ \\
\hline 400 & $8 / 8$ & 3 & 384 \\
\hline 200 & $8 / 9$ & 4 & 396 \\
\hline 100 & $13 / 15$ & 3 & 331 \\
\hline 50 & $6 / 7$ & 5 & 234 \\
\hline 25 & $5 / 6$ & 2 & 384 \\
\hline All doses & $40 / 45$ & 3 & 295 \\
\hline
\end{tabular}

TABLE 2. Haemagglutination inhibition (HI) responses of volunteers to $\mathrm{A} /$ Port Chalmers surface antigen vaccine (alb subjects)

\begin{tabular}{|c|c|c|c|c|}
\hline \multirow[b]{2}{*}{$\begin{array}{l}\text { Dose } \\
\text { (i.u.) }\end{array}$} & \multirow[b]{2}{*}{$\begin{array}{l}\text { Seroconversion } \\
\text { rate }\end{array}$} & \multicolumn{2}{|c|}{ g.m.t. } & 윽 \\
\hline & & $\begin{array}{c}\text { Pre- } \\
\text { vaccination }\end{array}$ & $\begin{array}{c}\text { Post- } \\
\text { vaccinatio }\end{array}$ & n. \\
\hline 400 & $11 / 12$ & 11 & 543 & $c$ \\
\hline 200 & $10 / 11$ & 6 & 612 & \\
\hline 100 & $22 / 24$ & 13 & 550 & \\
\hline 50 & $9 / 10$ & 13 & 384 & $c$ \\
\hline 25 & $9 / 10$ & 13 & 384 & O \\
\hline All doses & $61 / 67$ & 11 & 501 & $\rightleftarrows$ \\
\hline
\end{tabular}

all subjects are considered (Table 2 ) there is a sugges: tion of a lower level of response at doses of 50 and 25 i.u. but the differences are not statistically signi $\frac{\mathrm{O}}{\mathbb{Q}}$ ficant. 
With neuraminidase antibody, on the other hand (Table 3 ) there is a very marked fall in response to doses below 200 units.

TABle 3. Neuraminidase antibody responses to different doses of A/Port Chalmers neuraminidase

\begin{tabular}{cccc}
\hline \multirow{2}{*}{$\begin{array}{c}\text { Dose } \\
\text { arbitrary } \\
\text { units of } \\
\text { activity) } \\
\text { (i.u.) }\end{array}$} & $\begin{array}{c}\text { Seroconversion } \\
\text { rate }\end{array}$ & $\begin{array}{c}\text { Pre- } \\
\text { grecination }\end{array}$ & $\begin{array}{c}\text { Post- } \\
\text { vaccination }\end{array}$ \\
\hline 400 & $10 / 12$ & $<5$ & $15 \cdot 5$ \\
200 & $10 / 11$ & $<5$ & $15 \cdot 9$ \\
100 & $15 / 24$ & $<5$ & $11 \cdot 2$ \\
50 & $8 / 10$ & $<5$ & $8 \cdot 3$ \\
25 & $3 / 10$ & $<5$ & $2 \cdot 4$ \\
\hline
\end{tabular}

It has been suggested that subunit vaccines produce a narrower HI response than do whole virus vaccines. This does not, however, seem to be the case with our adsorbed preparations, since the spectrum of antibody response in six subjects, all of whom had an HI titre of $1: 12$ before vaccination, was broad (as seen in Table 4).

Table 5 shows the antibody response in elderly subjects to purified surface antigen vaccine, and although it does not appear to be as good as in young adults, it is adequate. Table 6 shows the results of a challenge study in student volunteers who received 400 i.u. of a surface antigen vaccine prepared from
TABLE 5. Homologous haemagglutination inhibition (HI) response in elderly subjects to A/Port Chalmers surface antigen vaccine. Twenty-eight subjects aged 65-76 (mean 71.3) years

\begin{tabular}{|c|c|c|c|}
\hline \multirow[b]{2}{*}{$\begin{array}{l}\text { Pre-vacen } \\
\text { HI titre }\end{array}$} & \multirow[b]{2}{*}{$\begin{array}{c}\text { Sero } \\
\text { conversion }\end{array}$} & \multicolumn{2}{|c|}{ g.m.t. } \\
\hline & & $\begin{array}{c}\text { Pre- } \\
\text { vaccination }\end{array}$ & $\begin{array}{c}\text { Post- } \\
\text { vaccination }\end{array}$ \\
\hline $\begin{array}{c}<20 \\
30-120 \\
\text { Total }\end{array}$ & $\begin{array}{l}19 / 22 \\
5 / 6 \\
24 / 28(86 \%)\end{array}$ & $\begin{array}{r}<20 \\
38 \\
<20\end{array}$ & $\begin{array}{r}127 \\
1599 \\
218\end{array}$ \\
\hline
\end{tabular}

the A2/Eng/42/72 strain and were subsequently challenged with the attenuated MRC-7 recombinant. As can be seen, the incidence of a successful challenge in the control group was $57 \%$ compared with approximately $4 \%$ in the vaccinated subjects.

\section{Discussion}

Previous studies in ferrets (Brady and Furminger, 1975) had shown that a vaccine prepared from purified influenza haemagglutinin and neuraminidase was effoctive in protecting these animals against challenge infection with the homologous strain of virus. It was therefore of interest to investigate the antibody response and reactogenicity in human subjects and the response of volunteers to direct challenge with an attenuated virus.

The lack of any general reactions and the absence of any reports of severe local reactions to the surface

TABLE 4. Heterologous antibody response to haemagglutinin of $\mathrm{A} /$ Port Chalmers/73. Six subjects all with A/Port Chalmers titre of $<1: 12$ prevaccination

\begin{tabular}{lccrrr}
\hline \multicolumn{5}{c}{ Viruses } \\
\cline { 2 - 6 } Subject & A/Scot/74 & A/S.Aust/74 & x31 & A/42/74 & A/PC \\
\hline A.B. & 384 & 96 & 384 & 192 & 96 \\
B.Y. & 3072 & 768 & $>6144$ & 3072 & 6144 \\
M.B. & 768 & 192 & $>6144$ & 1536 & 384 \\
M.S. & 48 & 24 & 96 & 24 & 48 \\
M.C. & $>6144$ & 3072 & $>6144$ & $>6144$ & $>6144$ \\
J.R. & 48 & 24 & 96 & 192 & 24 \\
\hline
\end{tabular}

TABLE 6. Infection with MRC-7 virus in volunteers previously given A2/Eng/42/72 vaccine, and in controls

\begin{tabular}{ccccccc}
\hline & & \multicolumn{3}{c}{ Infection with MRC-7 by } \\
\cline { 3 - 6 } Group & $\begin{array}{c}\text { Serum HI } \\
\text { antibody } \\
\text { titre* }\end{array}$ & $\begin{array}{c}\text { No. } \\
\text { tested }\end{array}$ & $\begin{array}{c}\text { Virus } \\
\text { isolation }\end{array}$ & $\begin{array}{c}\text { Significant (x4) } \\
\text { HI antibody } \\
\text { response }\end{array}$ & Total & $\begin{array}{c}\text { Total } \\
(\%)\end{array}$ \\
\hline Vaccinees & $<20$ & 15 & $0 / 12$ & $1 / 15$ & $1 / 15$ & $1 / 23$ \\
& $20-40$ & 4 & $0 / 2$ & $0 / 4$ & $0 / 4$ & $(4 \cdot 3 \%)$ \\
Controls & $>60$ & 4 & $0 / 3$ & $0 / 4$ & $0 / 4$ & $13 / 23$ \\
& 20 & 15 & $3 / 11$ & $10 / 15$ & $10 / 15$ & $1 / 4$ \\
& $20-40$ & 4 & $0 / 4$ & $2 / 4$ & $1 / 4$ & $(57 \%)$ \\
\hline
\end{tabular}

* Serum HI antibody titres before immunization. 
antigens suggests that the further purification involved in removing core and matrix proteins has resulted in a more satisfactory vaccine. The additional purity may also account for the flatness of the dose response curve to the haemagglutinin, by minimizing the extent of antigenic competition.

A similarly flat dose response has been observed in chickens, but the bird-to-bird variation makes this species an unsatisfactory test animal for standardization of the vaccine.

Further studies are in progress to assess the duration of the antibody response and to study the response of volunteers to challenge infections after graded doses of antigen.

\section{Acknowledgments}

We are indebted to Dr C. W. Potter of the Department of Medical Microbiology, University of Sheffield, for the information in Tables 5 and 6.
We thank Miss A. M. Bevan for help with the automated assays, Mr J. Eastwood for photography, Mr B. Getty for electron-microscopy and the numerous volunteers at Speke@ and Sheffield.

\section{References}

Bevan, A.M., Furminger, I.G.S. \& Smith, C.H. (1975)을 Neuraminidase assay of influenza vaccines. Internationalo Symposium on Immunity to Infections of the Respiratory System. Developments in Biological Standardization, 18, 173.

BraDY, M.I. \& FURMINGER, I.G.S. (1975) The protection of ferrets against influenza by immunization with a split influenza vaccine. International Symposium on Immunity to. Infections of the Respiratory System. Developments in Biological Standardization, 28, 167.

Brand, C.M. \& SkeHel, J.J. (1972) Crystalline antigen from the influenza virus envelope. Nature, New Biology. London 238, 145.

OXFORD, J.S. (1974) Personal communications.

Schild, G.C., Henry-Aymard, M. \& Periera, H.G. (1972) N A qualitative single radial diffusion test for immunologicalo studies with influenza virus. Journal of General Virology, $\infty$ 16, 231. 